\title{
Pemahaman Penanaman Empat Pilar Kebangsaan terhadap Siswa SMA Negeri 4 Medan
}

\section{Understanding of Investments Four Pilar of Nationality on Students State Senior High School 4}

\author{
Nina Angelia* \\ Program Studi Administrasi Publik, Fakultas Ilmu Sosial dan Ilmu Politik \\ Universitas Medan Area, Indonesia
}

\begin{abstract}
Abstrak
Penelitian ini untuk menjelaskan hubungan pemahaman empat pilar kebangsaan dengan sikap siswa menghadapi perkembangan zaman yang semakin berkembang. Rumusan masalah dari penelitian ini adalah bagaiman hubungan pemahaman empat pilar kebangsaan dengan sikap siswa. Metode penelitian yang digunakan dalam penelitian ini adalah metode deskriptif korelasional. Sampel penelitian berjumlah 44 responden. Teknik pengumpulan data yang digunakan dalam penelitian ini adalah wawancara dan dokumentasi. Berdasarkan hasil penelitian yang telah dilakukan dapat diketahui bahwa terdapat derajat kerataan.
\end{abstract}

Kata Kunci: Pemahaman, Penanaman, Empat Pilar Kebangsaan, Sikap dan Siswa

\section{Abstract}

This research is to explain the understanding of four pillars of nationality with students' attitudes facing the development of the growing era. The formulation of the problem of this research is how the relationship of understanding the four pillars of nationality with the attitude of students. The research method used in this research is correlational descriptive method. The sample of research is 44 respondents. Data collection techniques used in this study are interviews and documentation. Based on the results of research that has been done can be seen that there is degree flatness.

Keywords: Understanding, Planting, Four Pillars of Nationality, Attitude and Students

How to Cite: Angelia, N., (2017). Pemahaman Penanaman Empat Pilar Kebangsaan terhadap Siswa SMA Negeri 4 Medan. JPPUMA: Jurnal Ilmu Pemerintahan dan Sosial Politik UMA, 5 (1): 15-20.

*Corresponding author:
E-mail: ninaangelia@staff.uma.ac.id p-ISSN: 25491660 e-ISSN: 2550-1305 


\section{PENDAHULUAN}

Semangat kebangsaan di perlukan dalam kehidupan berbangsa dan bernegara. Perkembangan jaman dan globalisasi, semangat kebangsaan generasi muda umumnya dan siswa dan siswi SMA khususnya mulai menghilang. Oleh karena itu, sekarang ini sedang di canangkan lagi oleh pemerintah kesadaran menumbuhkan rasa kebangsaan dengan pembangunan karakter bangsa melalui empat pilar kebangsaan yang ada pada, Pancasila, Undang-Undang Dasar 1945, Negara Kesatuan Republik Indonesia dan Bhinneka Tunggal Ika.

Bangsa Indonesia merupakan bangsa yang lahir karena keanekaragaman dan perbedaan yang dipersatukan oleh kesadaran bersama untuk hidup sebagai bangsa yang merdeka dan berdaulat. Dengan keberagaman inilah yang menjadi identitas nasional bangsa Indonesia yang harus dipertahankan agar tidak luntur karena kemajuan zaman yang sangat pesat pada saat ini. Kemajuan zaman yang terjadi saat ini dapat mempengaruhi pemahaman generasi penerus bangsa terutama pada siswa terkait dengan nilainilai yang terkandung dalam Pancasila semakin terlupakan dan terkikis oleh adanya nilai-nilai baru yang tidak sesuai dengan jati diri bangsa. Ironisnya, tanpa disadari generasi muda bergerak semakin menjauh dari Pancasila sebagai jati diribangsa yang bercirikan semangat gotong royong.

Anak adalah tonggak sebuah negara, yang menentukan maju mundurnya pembangunan masyarakat, berperan sebagai generasi muda memiliki potensi dan penerus cita-cita bangsa Indonesia serta mempunyai peranan strategis, yang perlu pembinaan dan pengarahan dalam rangka menjamin pertumbuhan dan perkembangan fisik, mental, dan sosial secara utuh serasi, selaras dan seimbang. Pengawasan sosial dan pembentukan karakter kepada anak atau para siswa sudah banyak dilakukan oleh pihak pemerintah tetapi masih saja lemah, tindakan kriminal pada anak terus meningkat seperti tercermin pada kenakalan anak, geng motor, kejahatan, pencurian, minuman keras, narkoba, pelecehan seksual dan masih banyak lagi. Sehingga hal ini menyebabkan terjadinya keresahan masyarakat terhadap tindak kejahatan siswa, kejahatan- kejahatan yang dilakukan dengan sadis dan kejam, dimana para pelakunya melibatkan bukan hanya remaja tetapi juga oleh anak- anak dibawah umur. Bentuk-bentuk kenakalan remaja yang sebelumnya masih dianggap wajar tetapi beberapa tahun belakangan ini telah berubah menjadi tindakantindakan kriminal yang sangat mengganggu dan sangat meresahkan masyarakat.

Fenomena mengenai Persoalan tindak kriminalitas yang dilakukan pada anak menjadi sorotan banyak pihak di Kota-kota Besar Indonesia termasuk kota medan.Komisi Nasional Perlindungan Anak (Komnas PA) mencatat sebanyak 2.008 kasus kriminalitas yang dilakukan anak usia sekolah di sepanjang kuartal pertama 2012 jumlah itu meliputi jenis kejahatan seperti pencurian, tauran, narkoba, dan pelecehan seksual yang dilakukan siswa SD hingga SMA. Angka kriminalitas yang dilakukan anak usia sekolah cenderung meningkat setiap tahunnya, dari data yang diperoleh Komnas PA pada tahun 2010 terjadi 2.413 kasus kriminal anak usia sekolah, jumlah itu kemudian meningkat di 2011 yakni sebanyak 2.508 kasus (waspada,15 mei 2012). Tindak kriminalitas yang dilakukan oleh para remaja, hampir setiap hari berbagai media masa memberitakan tindakan kriminalitas yang dilakukan oleh remaja yang sangat meresahkan masyarakat.

Maraknya pemberitaan media masa tentang tindak kriminalitas pada anak di Kota Medan belakangan ini yang meresahkan masyarakat. Salah satunya Badan Narkotika Nasional (BNN) Provinsi Sumatera Utara menyatakakan Provinsi Sumatera Uatara khususnya kota Medan sudah masuk ke sekolah-sekolah dan melibatkan siswa Sekolah Dasar (SD) , 
selain itu BNN menyatakan baru-baru ini BNN menemukan siswa SD di Kota Medan terlibat pengguna narkoba, bahkan juga masuk kedalam jaringan pengedar narkoba (Tempo, 27 Februari 2014). Selain pemberitaan mengenai narkoba, tindakan kriminalitas yang dilakukan pada siswa adalah gank motor yang sangat menggangu ketertiban umum namun juga menimbulkan korban (Poskota, 22 Agustus 2011), tindakan pencurian, perampasan, penganiyaan, perusakan dan sebagainya berkali-kali terjadi.(Ekspsnews, 26 September 2011).

Merujuk dari data diatas dari berbagai info yang dikumpulkan menggambarkan bentuk dari kelalain orangtua, para pengajar, dan pemerintah yang kurang memperhatikan dan melindungi hak anak sehingga anak sebagai generasi bangsa yang harusnya dapat menjadi tonggak kuat sebuah negara akan dapat hancur begitu saja karena kita semua telah lalai dan tidak tanggap dalam mengasuh dan mendidik mereka. anak bagaikan selembar kertas putih yang dimana harus siap diisi tulisan dengan berbagai tinta-tinta kehidupan yang baik untuk mereka.

Dari dasar inilah pentingnya adanya penanaman nilai- nilai luhur bangsa sejak dini kepada anak-anak bangsa untuk memperkuat karakter generasi muda sebagai penerus pembangunan masyarakat Indonesia. Karena para anak bangsa adalah generasi penerus bangsa yang dapat mewujudkan mimpi-mimpi bangsa, jika anak bangsa pada saat ini pandai untuk mengeluarkan atau mengelola potensipotensi yang ada dalam diri mereka masing-masing. Penguatan karakter sangatlah perlu ditanamkan dalam diri para generasi muda sebab karakter merupakan akar sekaligus cerminan dari budaya bangsa.

Apabila semua para generasi muda memiliki karakter yang kuat dan unggul, maka negara kita akan terlihat sebagai bangsa yang pantas menjadi contoh pada negara-negara lain. Dan untuk mewujudkan hal itu, selain memiliki karakter yang unggul juga harus didampingi oleh 4 pilar kebangsaan agar bangsa kita menjadi lebih baik daripada sebelumnya dengan memperoleh negara yang maju dan masa depan bangsa yang lebih cerah. Karakter generasi muda dapat terbentuk jika 4 pilar selalu menopang atau menjadi pegangan bagi para generasi muda.

Hampir bisa dipastikan bahwa nilainilai dalam 4 pilar bangsa sudah mula pudar di kalngan generasi muda berdasarkan data-data moral dan kriminalitas yang banyak dilakukan generasi muda, yang seharusnya generasi muda hanya fokus kepada pendidikan yang bertujuan untuk membangun bangsa. Sekolah merupakan lembaga yang mendidik karakter bangsa juga tidak sepenuhnya menjamin keberhasilan generasi muda, kewajiban penanaman nilai-nilai bangsa bagi generasi muda harus dilakukan disekolah- sekolah termasuk di SMA Negeri 4 Medan

\section{METODE PENELITIAN}

Metode yang digunakan dalam penelitian ini adalah metode deskripsi korelasional yang bertujuan untuk menjalankan hubungan antara konsepkonsep atau nilai-nilai dari veriabelvariabel yang satu dengan variabel yang lain. Metode ini meneliti masalah-masalah aktual yang berlangsung dilapangan khususnya mengenai hubungan pemahaman empat pilar kebangsaan terhadap perilaku siswa dalam menyikapi perkembangan globalisasi.

Populasi dalam penelitian ini adalah seluruh sisa kelas IX di SMA Negeri 4 Medan yang berjumlah 440orang. Sampel dalam penelitian ini diambil sebesar 10\% dari jumlah populasi yang ada yakni 440 peserta didik kelas XI SMA Negeri 4 Medan, maka diperoleh sebanyak 44 orang siswa.

\section{HASIL DAN PEMBAHASAN}

Pemahaman atau comprehension berasal dari kata dasar "paham", yang berarti mengerti atau menguasai sesuatu. 
Menurut Arikunto (2008:118) "pemahaman merupakan bagaimana seseorang mempertahankan, membedakan, meduga, menerangkan, memperluas, menyimpulkan, menggeneralisasikan, memberikan contoh, menulis kembali dan memperkirakan contoh, menulis kembali dan memperkirakan"

Sudjana (2010:24) membagi pemahaman kedalam tiga katagori, yakni sebagai berikut:

Tingkat pertama atau tingkat terendah, yaitu pemahaman terjemahan, mulai dari terjemahan dalam arti sebenarnya; Tingkat kedua adalah pemahaman penafsiran, yakni menghubungkan bagian-bagian terdahulu dengan yang diketahui berikutnya, atau menghubungkan beberapa bagian dari grafik dengan kejadian, membedakan yang pokok dan yang bukan pokok; Pemahaman tingkat tinggi yaitu pemahaman ekstrapolasi. Dengan ekstrapolasi diharapkam mampu melihat di balik yang tertulis, dapat membuat ramalan tentang konsekwensi atau dapat memperluas persepsi dalam arti waktu, dimensi, kasus, ataupun masalahnya.

Secara umum dikatakan bahwa pilar merupakan tiang penyangga suatu bangunan. Dalam bahasa jawa tiang penyangga bangunan atau rumah ini disebut 'soko', yakni rumah yang atapnya menjulang tinggi terdapat empat soko di tengah bangunan yang disebut soko guru.

Menurut sosialisasi MPR RI tentang empat pilar Kehidupan Berbangsa dan Bernegara (2012), empat pilar dipandang sebagai suatu yang harus di pahami oleh para penyelenggaraan negara bersama seluruh masyarakat dan menjadi panduan dalam kehidupan berpolitik, mejalankan pemerintahan, menegakkan hukum, mengatur perekonomian negara, interaksi sosial kemasyarakatan, dan berbagai dimensi kehidupan bernegara dan berbangsa lainnya. Dengan pengamalan prinsip Empat Pilar Kehidupan Berbangsa dan Bernegara, diyakini bangsa Indonesia akan mampu mewujudkan diri sebagai bangsa yang adil, makmur, sejahtera, dan bermartabat.

Menurut sosialisasi MPR RI tentang empat Pilar Kehidupan Berbangsa dan Bernegara (2012:11), Pancasila merupakan dasar negara yang mempersatukan bangsa sekalipun bintang penuntun yang dinamis, yang mengarhkan bangsa dalam mencapai tujuannya. Dalam posisinya seperti itu, Pancasila merupakan sumber jati diri, kepribadian, moralitas, dan haluan keselamatan bangsa.

Dengan kata lain, Pancasila digunakan sebagai petunjuk arah semua kegiatan atau aktifitas hidup dan kehidupan di dalam segala bidang. Ini berarti bahwa semua tingkah laku/perbuatan setiap manusia Indonesia harus dijiwai dan merupakan pancaran dari semua sila Pancasila karena Pancasila sebagai waltanschauung selalu merupakan suatu kesatuan, tidak bisa dipisahpisahkan satu dengan yang lain.

Undang-Undang Dasar ialah hukum dasar yang tertulis, sedang di sampingnya Undang-Undang Dasar itu berlaku juga hukum dasar yang tidak tertulis, ialah aturan-aturan dasar yang timbul dan terpelihara dalam praktek penyelenggaraan negara meskipun tidak tertulis. Beberapa pihak membedakan antara pengertian konstitusi dan UndangUndang Dasar.

Menurut Soeprapto (2010: 33) menyatakan bahwa: Konstitusi berisi seluruh peraturan-peraturan dasar, baik yang tertulis maupun yang tidak tertulis, yang berisi perinsip-perinsip dan normanorma hukum yang mendasari kehidupan kenegaraan, sedang undang-undang dasar hanya memuat bagian yang tertulis saja.

Hukum dasar negara Indonesia meliputi keseluruhan sistem ketatanegaraan yang berupa kumpulan peraturan yang membentuk Negara dan mengatur pemerintahannya. Oleh karena itu setiap produk hukum seperti undangundang peraturan atau keputusan pemerintah, termasuk kebijakan 
pemerintah harus berlandaskan dan bersumber pada peraturan yang lebih tinggi, yang pada akhirnya dapat dipertanggung jawabkan pada ketentuan UUD 1945.

Syarat berdirinya sebuah negara ada empat, yaitu memiliki wilayah, memiliki penduduk, memiliki pemerintahan dan adanya pengakuan dari negara lain. Dan karena memenuhi empat syarat itulah kemudian Negara Indonesia lahir dengan nama Negara Kesatuan Republik Indonesia (NKRI).

Pengertian Indonesia sebagai negara kesatuan dijelaskan oleh Kaelan (2012:197) bahwa:

Negara yang merupakan suatu kesatuan dari unsur-unsur yang membentuknya, yaitu rakyat yang terdiri atas berbagai macam etnis suku bangsa, golongan, kebudayaan serta agama. Wilayah yang terdiri atas beribu-ribu pulau. Oleh karena itu negara persatuan adalah merupakan suatu negara, satu rakyat, satu wilayah dan tidak terbagi-bagi misalnya seperti negara serikat, satu pemerintahan, satu tertib hukum nasional, satu bahasa serta bangsa yaitu Indonesia.

Jadi "negara persatuan" bukanlah negara yang berdasarkan individualisme sebagaimana diterapkan di negara liberal di mana negara hanya merupakan suatu ikatan individu saja.

Menurut sosialisasi MPR RI tentang Empat Pilar Kehidupan Berbangsa dan Bernegara (2012) berbunyi lengkap dari ungkapan Bhinneka Tunggal Ika dapat ditemukan dalam Kitab Sutasoma yang ditulis oleh Mpu Tantular menulis "bahwa agama Budha dan siwa (Hindu) merupakan zat yang berbeda, tetapi nilainilai kebenaran jina (Budha) dan siwa adalah tunggal. Terpecag belah, tetapi satu jua, artinya tak ada dharma yang mendua)

Semboyan Bhineka Tunggal Ika mulai menjadi pembicaraan terbatas pertama kali antara Muhammad Yamin, Bung Karno dan I Gusti Bagus Sugriwa dalam sidang-sidang BPUPKI sekitar dua setengah bulan Proklamasi. Bahkan Bung
Hatta sendiri mengatakan bahwa Bhinneka Tunggal Ika adalah ciptaam Bung Karno setelah Indonesia merdeka. Setalah beberapa tahun kemudian ketika merancang lembaga negara Republik Indonesia dalam bentuk Garuda Pancasila, semboyan Bhinneka Tunggal Ika dimasukkan ke dalamnya.

Berdasarkan hasil analisis data dari 7 pertanyaan yang diberikan kepada 44 responden diperoleh data yaitu: nilai tertinggi (NT) adalah 23,3, nilai terendah (NR) adalah 6,6 dengan 3 katagori. Sehingga dapat diketahui bahwa sebanyak 24 responden $(56 \%)$, siswa cenderung cukup paham dalam memahami pancasila sebagai dasar Negara. Idiologi bangsa dan nilai-nilai yang terkandung dalam Pancasila lainnya.

Berdasarkan hasil analisis data dari 10 pertanyaan yang diberikan kepada 44 responden diperoleh data yaitu: nilai tertinggi (NT) adalah 30, nilai terendah (NR) adalah 6,6 dan dengan 3 katagori. Sehingga dapat diketahui bahwa sebanyak 27 responden $(60 \%)$ siswa cenderung cukup paham dalam memahami UndangUndang Dasar 1945 sebagai dasar hukum Negara Republik Indonesia, Konstitusi, hasil amandemen dan ketentuan tatacara perubahan UUD.

Berdasarkan hasil analisis data dari 9 pertanyaan yang diberikan kepada 44 responden diperoleh data yaitu: nilai tertinggi (NT) adalah 23,3, nilai terendah (NR) adalah 6,6 dan dengan 3 katagori. Sehingga dapat diketahui bahwa sebanyak 28 responden (63\%), siswa cebderung cukup paham dalam memahami NKRI meliputi, pengertian negara, unsur-unsur terbentuknya Negara, bentuk-bentuk negara dan sumber hukum Negara.

Hasil analisis data dari 5 pertanyaan yang diberikan kepada 44 responden diperoleh data yaitu: nilai tertinggi (NT) adalah 12, nilai terendah (NR) adalah 7 dam dengan 3 katagori. Sehingga dapat diketehui bahwa sebanyak 21 responden (57\%) siswa dalam lingkup penelitian ini cenderung sangat setuju terhadap adanya informasi. Komunikasi dan teknologi 
Nina Angelia. Pemahaman Penanaman Empat Pilar Kebangsaan terhadap Siswa SMA Negeri 4

dalam membantu siswa untuk mencari yang dibutuhkan siswa dan guru.

\section{SIMPULAN}

Berdasarkan hasil pengelolaan data yang telah dilakukan maka dapat disimpulkan ada hubungan terhadap pemahaman empat pilar kebangsaan dengan sikap siswa di SMA Negeri 4 Medan. Pada variabel pemahaman empat pilar kebangsaan yang meliputi pancasila, UUD 1945, NKRI Dan Bhineka Tunggal Ika, tingkat pemahaman siswa mengarah kepada cukup paham yaitu dengan jumlah rata- rata dari keempat indikator sebesar $59 \%$.

\section{DAFTAR PUSTAKA}

Driyarkarya,198o, Tentang Pendidikan,Yayasan Kanisius,Jakarta

Kalan, 2012, Problem Epistemologi Empat Pilar Berbangsa dan Bernegara, Paradigma: Yogyakarta

Kartono, K.,1996, Landasan Manajemen Pendidikan Remaja, Rosdakarya: Bandung

Soetomo, 2011, Masalah Sosial, Pustaka Pelajar: Jakarta 